\title{
People, trees and forests in 2020: Is there a role for the forest industry ${ }^{1}$
}

\author{
by Jean-Pierre Martel $^{2}$
}

We've been asked today to do the impossible - determine the role of the forest industry in 2020.

For someone who has trouble planning for the next weekend - this is a difficult task indeed. And if I had such clairvoyant powers, I would have sold all my technology stocks about a year ago and bought a couple of oil wells. Defining the forest industry 20 years from now is a considerable challenge when we don't know with any certainty what it will look like one year from now. Or more to the point, what the forest products markets will look like a year from now.

A sage once said that those who ignore history are doomed to repeat it. With that in mind, I'd like to begin by bringing to you an important historical perspective from nearly 20 years ago — and it is a personal perspective that still plays a significant role in my own vision of forestry.

In 1981, I was about to graduate from Laval University's Faculty of Forestry. One of my professors and mentors was the late Dr. Marcel Lortie, with whom I'm sure many of you are familiar. In a characteristically straightforward manner, Dr. Lortie said to me "Jean-Pierre, soon you will be a forestry engineer. Could you tell me what you learned over the last four years?"

Where to start? I listed all the topics I'd studied, the courses I'd taken-but after each example he always asked "what else?" When finally I ran out of words, he said I should never forget that "On ne fait pas de la foresterie pour les arbres, mais pour les hommes!" ("We are not practising forestry for the trees but for men!').

That's the best professional advice I have ever received, and his words are fresh in my mind even today. They make that impossible task of looking to the future not so impossible after all. With that kind of vision, you can look ahead - perhaps not with certainty — but at least with a clear direction in mind.

Forestry and forest management-for private companies operating on public lands-is about meeting the needs of the people. Their needs are all encompassing - for timber and non-timber resources like shelter, communications, packaging, recreation, wildlife, water, etc. To maintain our legal, and moral, license to operate on Canadian public land, we must continue to adapt to the ever-changing societal values and expectations. At the same time, we must maintain or improve our competitiveness and access to the continually growing global marketplace.

Many of us have already learned these lessons - and we learned them the hard way. This is particularly true for our colleagues on the West Coast. Different people have vastly different expectations of what the forest should provide. Clayoquot Sound and, more recently, the Great Bear Rainforest are prime examples of how those differences can result in conflict, and

\footnotetext{
${ }^{1}$ Presentation to the Canadian Institute of Forestry, Whistler, British Columbia, August 14, 2001

${ }^{2}$ Manager, Strategic Issues, Weyerhaeuser Company Limited. E-mail: JeanPierre.Martel@weyerhaeuser.com
}

show up every night on the TV news. Again, history that should not be ignored.

To better illustrate how the relationship between forest and people has evolved, I've created a table that outlines the values important to a wide variety of stakeholders (Table 1). They show quite graphically how expectations have changed over the years. And I believe they also show that the pace of change will not slow down.

Before we can begin to understand what the forest industry

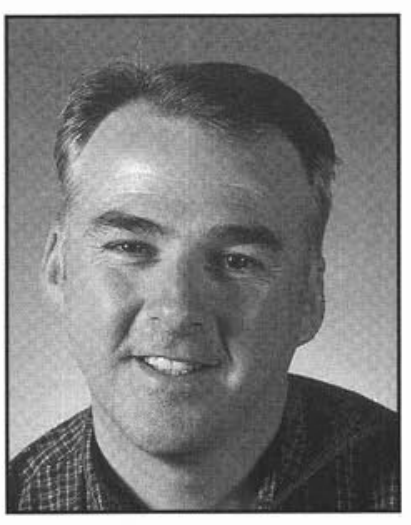

Jean-Pierre Martel might look like in another 20 years, we must have a clear understanding of the future demand for its products. Recent studies and forecasting models show that the world demand for timber will increase in the future. Population growth and improved living standards as well as expanding education and improved global and national economies will drive this increase. Figs. 1 and 2 present some of the results of a recent RISI study.

Fig. 1 shows that the annual world demand for wood fibre will increase drastically from 1990 to 2020 , going from 400 million $\mathrm{m}^{3}$ to over 850 million $\mathrm{m}^{3}$. It demonstrates that more hardwood and softwood fibre will be needed to meet the increasing world demand for pulp and paper products and engineered wood products. Fig. 2 shows that the world demand for saw logs is expected to stabilize at about 1 billion $\mathrm{m}^{3} /$ year with an increased demand in hardwood lumber.

But while the demand for wood fibre and saw logs will grow, so too will the need for the wide array of non-timber values associated with a standing forest. This is especially true for recreation, where we will see a decline in traditional activities such as fishing and hunting and an increase in the popularity of ecotourism and the need to preserve aesthetic values. The potential for conservation credits will also increase for water and soil conservation, carbon sequestration, and biodiversity conservation values (wildlife/habitat, endangered species, consumptive and medicinal plants, etc.)

Private forest products companies-if they want to survive and prosper in the year 2020 -will need to be intimately involved in all these values, and they will have to manage the forest resources to achieve sustainability at the local, national and global levels. I believe they will, for the following reasons: Only the private sector can provide the capital resources that are essential to a) manage the forest resources, b) to build/modernize processing facilities, c) for product and market development (global marketplace), and d) for research and development. Only the private sector provides a mechanism for an efficient and timely use of resources, as well as access to technical and marketing knowledge and expertise. And only the private sector can respond rapidly to changing market conditions and opportunities. 
Table 1. An evolving relationship between forest and people

- Communities

- Rural: economic growth, social stability, recreation

- Urban: recreation, aesthetic, ecological, Forest as a source of wealth?

- Employee: Quality of life (workplace + home), safety

- Customers: High-quality, low-price and hassle-free forest products

- First Nations: Resolve land claims, respect cultural and traditional values, promote economic and social development

- ENGOs: Environmental conservation (ecological services) and social equity

- Shareholders/Financial Community: Good return on investment and a growing social responsibility

- Industry: Global competitiveness, fibre security, stability, good return on investment, safety, social license to operate, market access, citizenship

- Governments: Balancing all the above, Being re-elected
But is the private sector doing all this now? In 1998, John Elkington published a book, Cannibal with Forks, which describes the triple bottom line concept. "All businesses can and must pick up the three-pronged fork of sustainability to help society achieve the interlinked goals of economic prosperity, environmental protection (stewardship), and social equity."

This concept is increasingly being adopted by the private sector in Canada and in other parts of the world. It clearly states that to be successful in the international marketplace, the private sector will have to achieve a proper balance between economic, environmental and social values.

For the Canadian forest sector, this means that our success is directly linked to our potential to adapt to societal changes. Table 2 outlines graphically the context in which the Canadian industry operates, and the context in which it must adapt to changing values. As you can see, we face many challenges. But the Canadian forest sector has the resources, the wealth, and the expertise to become the most sustainable sector of all. Can you
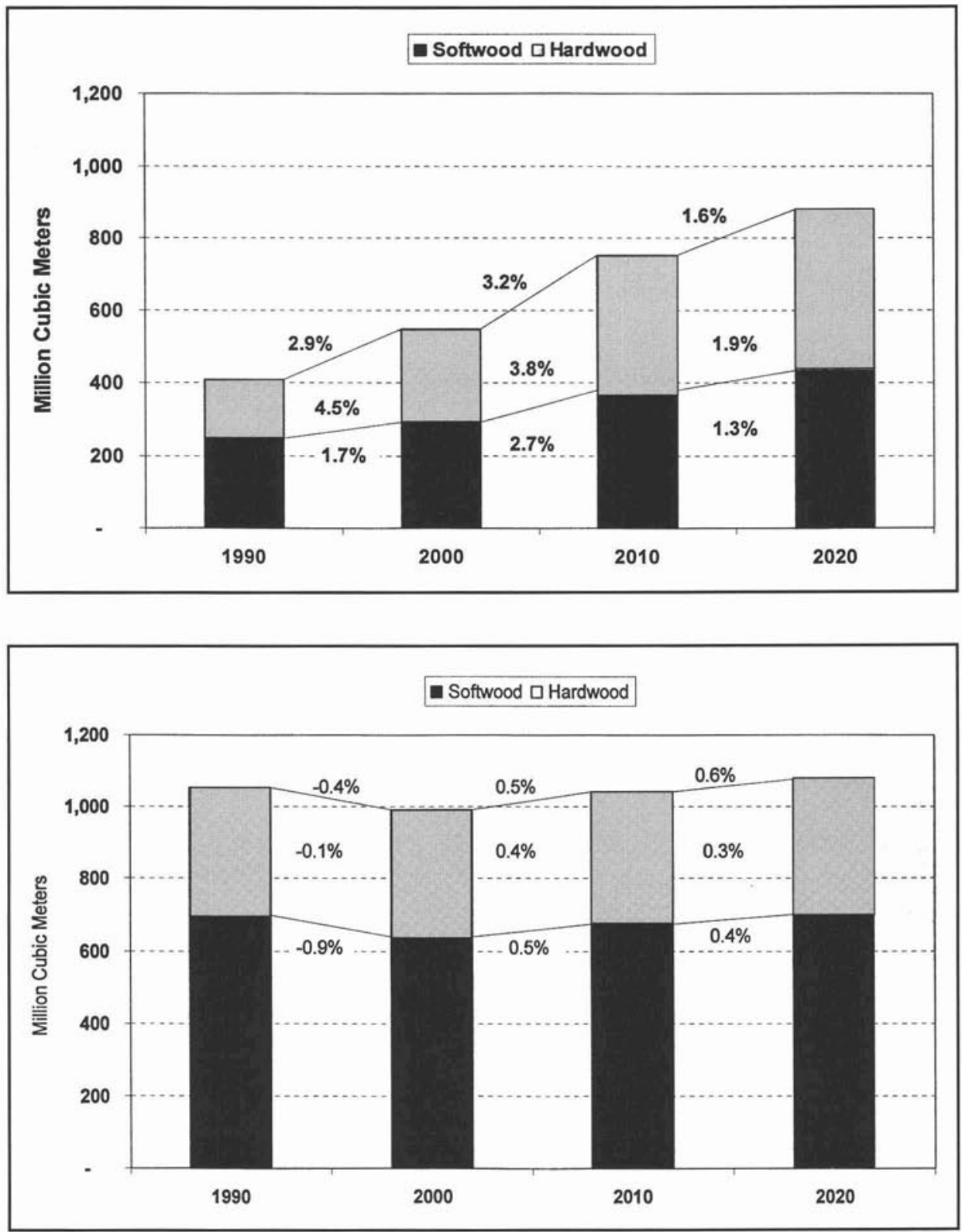

Fig. 1. World fibre log demand.

Fig. 2. World sawlog demand. 
Table 2. Canadian forest sector context

- Very diverse operating conditions

- Legal, ecological, cultural, social, etc.

- Large tracks of natural forests (e.g. coastal, boreal) with some of global significance

- Public forests with changing stakeholders expectations

- Unresolved land use issues

- Protection/Land claims/Managed forests

- Unresolved management regimes

- Ecologically based forest management/intensive forestry

- Competitiveness?

- Costs/quality/market acceptance/market access

- Image

- Traditional/sunset/low tech?

- Local issues going global almost instantly

name one other natural resource sector that could do it better? Name one other natural resource sector that puts back into nature more than it takes out.

It is imperative that all stakeholders work together to meet this collective challenge. We need to build on our strengths and be innovative in finding solutions that will lead us on the sustainability path. Table 3 summarizes suggestions of key actions that will need to be taken in Canada to achieve our common goal of sustainability. Some of the proposed actions will be difficult to implement and will need very innovative approaches and initiatives. To be successful, it will require that all stakeholders have an open and creative mind when developing solutions.

Weyerhaeuser is already exploring some of those avenues and is doing so with a two-pronged approach. First, we are committed to building bridges and offering constructive participation in initiatives designed to develop consensus with stakeholders on controversial issues. As an example, we support the B.C. mid-coast joint solution project, the Ontario Lands for Life Program, and other similar initiatives.

Secondly, we are continually testing new approaches to forest management to determine if they can be used under different circumstances. As an example, our B.C. Coastal Group Forest is implementing the "Forest Project," which includes a phasingin of variable retention harvesting in all our coastal operations by 2003. In addition, we are working with First Nations to develop new joint ventures and partnerships. One example is lisaak, a joint venture with five First Nations of Clayoquot Sound on the west coast of Vancouver Island to create a viable enterprise in a 100000 -ha forest with high conservation values. Another example is Wapawekka, a joint venture sawmill with three Indi-
Table 3. Build on our strengths to become the most sustainable sector

- Land use

- Complete network of protected areas

- Zoning (conservation, extensive and intensive forest management)

- Tenures

- Privatization of trees vs. long-term lease

- Explore new models (timber and non-timber resources)

- Promote long-term investments

- First Nations

- Landowners and development partners

- Diversity of management regimes

- Ecologically based forest management

- Role of intensive forestry on a small proportion of the land base where it makes sense

- Strong science-based sector

- Forest resources and services (conservation and production)

- Manufacturing (costs/quality/innovation)

- Product development (timber and non-timber)

- Modify management objectives and practices to reflect

- Scientific knowledge

- Societal values

- From SFM certification to sustainability certification

- Life cycle

- Sustainability (value chain: forest to customers)

- Wood the ultimate "Green Product"

- Build Support from Stakeholders

an bands in Prince Albert, Saskatchewan that has created economic benefits for aboriginal people in the sawmill and in the forest.

As I said at the beginning - it is impossible to predict what the forest sector will look like in 2020. But we can chart the right direction, based on a clear vision of where we want to go. I believe that we have already begun that process, and that we have already made some progress. Perhaps the biggest challenge will be to recognize that none of this is static; that values will continue to change; and that we will have to change with them.

Albert Einstein said: "The significant problems we face cannot be solved at the same level of thinking we were at when we created them." Therefore, the solution will come from the creativity and innovation within our sector. I am confident that we are up to the challenge. 